OPEN ACCESS

Edited by:

Sedat Sen,

Harran University, Turkey

Reviewed by:

Tuncer Akbay,

Mehmet Akin Ersoy University, Turkey Vanessa Scherman,

University of South Africa, South Africa

*Correspondence:

Mutale Sampa

mutalesampa65@gmail.com

Taryn Young

tyoung@sun.ac.za

Specialty section:

This article was submitted to Assessment, Testing, and Applied

Measurement,

a section of the journal

Frontiers in Education

Received: 05 October 2020 Accepted: 23 December 2020 Published: 08 February 2021

Citation:

Sampa M, Musukuma M, Fisa $R$ Musonda $P$ and Young T (2021) Interventions for Keeping Adolescent

Girls in School in Low- and MiddleIncome Countries: A Scoping Review.

Front. Educ. 5:614297.

doi: 10.3389/feduc.2020.614297

\section{Interventions for Keeping Adolescent Girls in School in Low- and Middle-Income Countries: A Scoping Review}

\author{
Mutale Sampa $^{1 *}$, Mwiche Musukuma ${ }^{1}$, Ronald Fisa ${ }^{1}$, Patrick Musonda ${ }^{1,3}$ and Taryn Young ${ }^{2 *}$ \\ ${ }^{1}$ Department of Epidemiology and Biostatistics, School of Public Health, University of Zambia, Lusaka, Zambia, ${ }^{2}$ Division of \\ Epidemiology and Biostatistics, Department of Global Health, Stellenbosch University, Stellenbosch, South Africa, ${ }^{3}$ University of \\ Bergen, Bergen, Norway
}

Background: Adolescent girls dropping out of school may lead to gender inequality, high illiteracy levels, single motherhood, unemployment, and many more undesirable outcomes that inhabit human capital development for girls. It is therefore important to put measures in place to support adolescent girls to stay in school. The objectives of the scoping review were to identify and describe the types of studies conducted to assess interventions for keeping adolescent girls in school and to describe these interventions in low- and middleincome countries.

Methods and Results: A comprehensive search was done in Epistemonikos, Social Science Citation index, Embase, OVID Medline, the Campbell Collaboration Library, and CENTRAL in March 2020. The search yielded 3,295 studies of which 18 studies were eligible for inclusion. All the 18 included studies were primary studies, and 12 out of these were randomized controlled studies. The other study designs of included studies were mixed-methods longitudinal design, random evaluation, cross section, etc. The interventions in the included studies were categorized as follows: provision of funding, school-based interventions for learners, community-based interventions, and education systems intervention. Provision of school fees, and other school supplies have shown evidence of reducing school dropouts, increasing enrolments and school attendance, while interventions like hygiene promotion and water treatment in a study done in Kenya found no significant evidence to support the observed effect on school attendance.

Conclusion: The scoping review found that several primary studies have been done on interventions to keep adolescent girls in school. However, there is need for more research to be done. Therefore, the authors propose to conduct a systematic review on the effect of provision of sanitary towels to adolescent girls on school retention in low- and middleincome countries.

Keywords: adolescent, dropout, intervention, randomized controlled trial, scoping review, retention 


\section{INTRODUCTION}

According to UNESCO Institute for Statistics (UIS), about 263 million children and youth were out of school in 2016. These include; 61 million children of primary school age, 60 million of lower secondary school age, and those in upper secondary school age at 142 million (UNESCO, 2016). Generally, girls are much more likely to be out of school than boys, reflecting their greater vulnerability to the key drivers of poor educational outcomes, including poverty, political instability/conflict, lack of accessible facilities, and lack of economic opportunities linked to education. Girls in rural areas are more likely to drop out of school than their male counterparts (Sandøy et al., 2016). Adolescent girls dropping out of school may have consequences such as high illiteracy levels, single motherhood, unemployment, little or no access to medical or health services, increased teenage pregnancies, and increased child mortality.

School dropout, child marriage, and early pregnancy are interrelated outcomes that have an enormous impact on adolescent girls (Sampa et al., 2018). Each year, 15 million girls are married before the age of 18 years in Africa. In Sudan, for example, $10.7 \%$ of women aged 15 to 49 years were married before the age of 15 years, and $38 \%$ were married before the age of 18 years (Nagar et al., 2017). Adolescent girls face health risks during pregnancy and childbirth, accounting for $15 \%$ of the Global Burden of Disease for maternal conditions and 13\% of all maternal deaths. (Neal et al., 2012). Furthermore, child marriage frequently ends a girls' education. Little or no schooling is associated with extreme poverty and hunger, gender inequality, increased child mortality, increased teenage pregnancy rates, and early sexual debut. Married adolescent girls tend to have limited or no social networks, restricted social mobility, little autonomy, and little or no access to media and health messages (Beattie et al., 2015).

A WHO (World Health Organization) review of adolescent pregnancy indicated that age may not be the only cause; factors such as education, social status, and use of health facilities are all contributing factors (Mcintyre, 2006). A study in Johannesburg, South Africa, revealed that teenage pregnancy, lack of parental involvement, substance abuse, and peer pressure, among others, were the causes of learner dropout (Mnguni, 2014). The income shocks that occur in poor households often force parents to pull their children from school and send them to the labor market. This can have a negative impact and long-term adverse consequences for the human capital development of the child (Kharisma et al., 2017).

The iterative logic model (Figure 1) illustrates some of the risk factors of adolescent girls dropping out of school as well as the consequences of dropping out of school, and the logic model was developed based on the literature reviewed. Risk factors for adolescent's dropping out of school can be categorized as social, economic, and academic, while some factors maybe biological like menstrual periods, with others being structural determinants such as perceptions of value, societal valuing of women, obligations at home, and expectations for child care. Social and demographic risk factors include age, ethnicity/race, parents' education level, and distance to school, while household income falls under economic factors. Academic risk factors include absenteeism, grade retention, special education placement, low performance and grades, and low educational expectations.

Proposed categorization of interventions aimed to keep adolescent girls in school included funding incentive interventions, community-based interventions, school-based interventions for learners, education systems interventions, and health systems intervention. With funding incentive interventions being those involving the provision of money, community-based interventions were interventions targeted at community members such as sensitization of community on the importance of keeping adolescent girls in school. School-based interventions for learners were defined as interventions done in schools for the benefit of the learners such as having a school helper to monitor school attendance, while education systems interventions were those targeted at training teachers in specific pedagogies for the benefit of the learners. Health system intervention was defined as interventions targeted at learners through the health sector. Providing reproductive health information and youth-friendly services to young people have been shown to increase educational attainment and reduces reproductive health risks, including early and unwanted fertility, and benefits their future families and society (Murphy and Carr, 2007). Cash transfers have the potential to increase and protect children's education by covering school expenses, compensating for lost income when children are sent to school rather than work, ensuring that children are better nourished at school, and providing an incentive for attendance when cash is conditional (Adota, 2009).

In order to achieve Sustainable Development Goal number 4.1, whose target is to "ensure that all girls and boys complete free, equitable and quality primary and secondary education leading to relevant and effective learning outcomes by 2030," effective interventions to ensure that both girls and boys stay in school need to be implemented. Therefore, the purpose of the scoping review was to identify and describe the types of studies conducted to assess interventions for keeping adolescent girls in school and also to describe the interventions implemented to keep adolescent girls in school in low- and middle-income countries (LMICs) and to expand the iterative logic model based on the findings of the review. The main outcome of the scoping review was keeping adolescent girls in school referring to girls being able to complete their primary as well as secondary school education.

\section{METHODS}

Scoping reviews are useful to examine the extent of research available, for identification of knowledge gaps, setting research agendas, and identifying implications for decision-making (Tricco, 2016). The methodology used was based on the methodology by Arksey and O'Malley which comprised five principal stages, namely, identifying the research question, identifying relevant studies, study selection, charting the data and collating, and summarizing and reporting the results (Arksey and O'malley, 2005). The methodology also followed the Joanna 


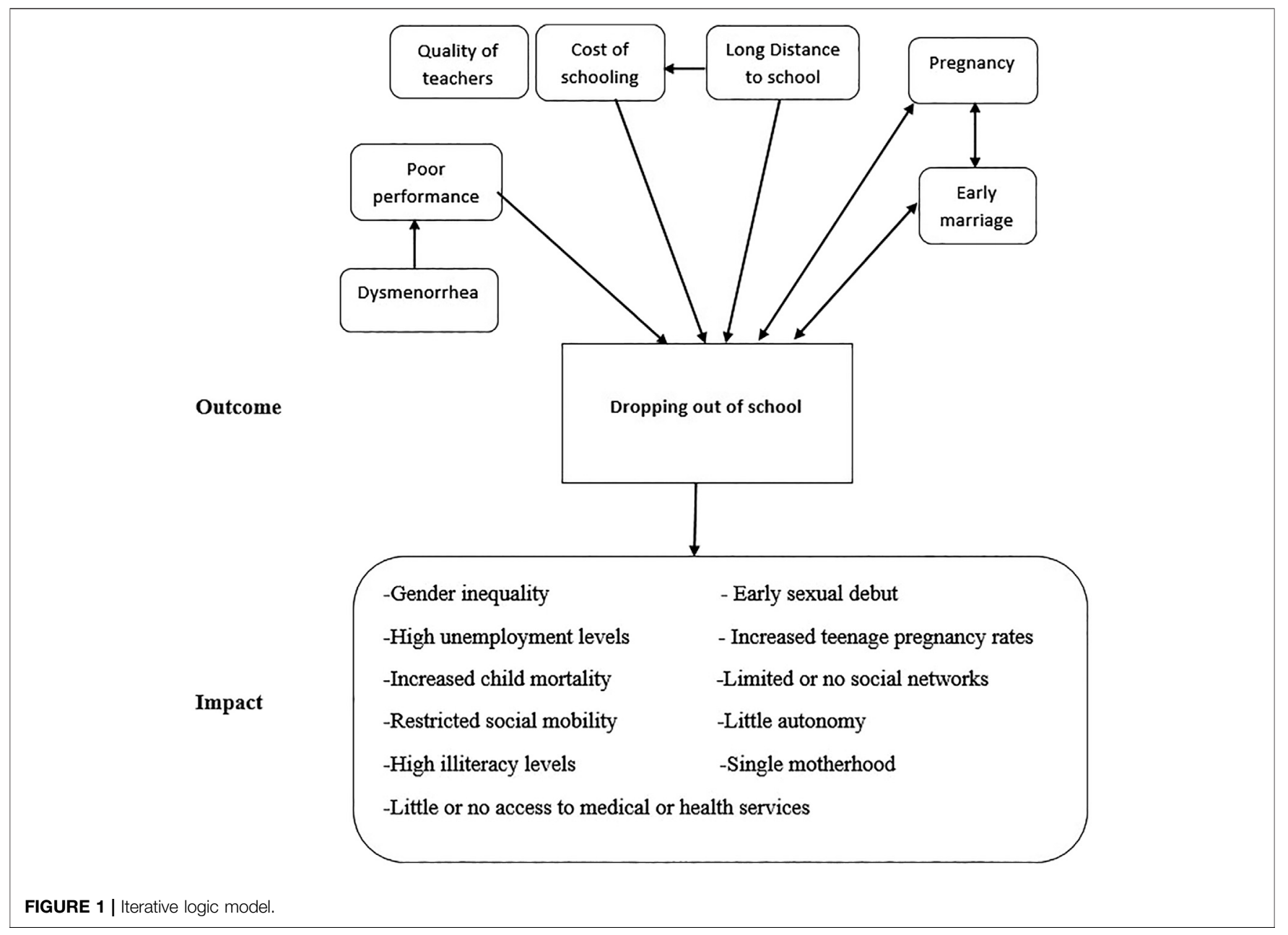

Briggs Institute (JBI) reviewers' manual on scoping reviews (Peters, 2015). The results have been reported following the PRISMA Extension for Scoping Reviews (Tricco, 2018).

\section{Criteria for Considering Studies and Reviews for Inclusion}

As the scoping review aimed to identify and describe the types of studies that had been conducted to assess interventions for keeping adolescent girls in school, it included all primary studies and systematic reviews done on interventions to keeping adolescent girls (aged 10-19 years) in school in LMICs as defined by the WHO (World Health Organization, 2019). Studies were considered regardless of their methodologies or year of publication, and all LMICs worldwide were eligible for inclusion in the scoping review. LMICs are countries whose gross national income is between $\$ 1,036$ and \$4,045 according to the World Bank, 2019. Countries such as India, Kenya, Zimbabwe, Nepal, and Zambia, and many more countries are classified as LMICs.

The review excluded studies that were conducted in middleincome countries and upper-income countries, studies that looked at both adolescent boys and girls with aggregated results were excluded, and studies that looked at girls outside the age range of 10-19 with aggregated results were also excluded from the review. Some studies were excluded because they had no intervention.

\section{Identification of Relevant Studies and Selection of Studies and Reviews}

A comprehensive search (Supplementary material) was done in Epistemonikos, Social Science Citation index, Embase, OVID Medline, the Campbell Collaboration Library, and CENTRAL in March 2020. The studies were uploaded into Covidence. Covidence is a software for managing and streamlining systematic review (Covidence systematic review software, 2019). Two reviewers independently screened the titles and abstracts; the two reviewers also independently screened the full texts of potential articles that were included at tittle and abstract screening stage. The elimination of irrelevant study was based on the inclusion and the exclusion criteria for the review. The third reviewer came on board to resolve conflicts that arose during the screening process. 


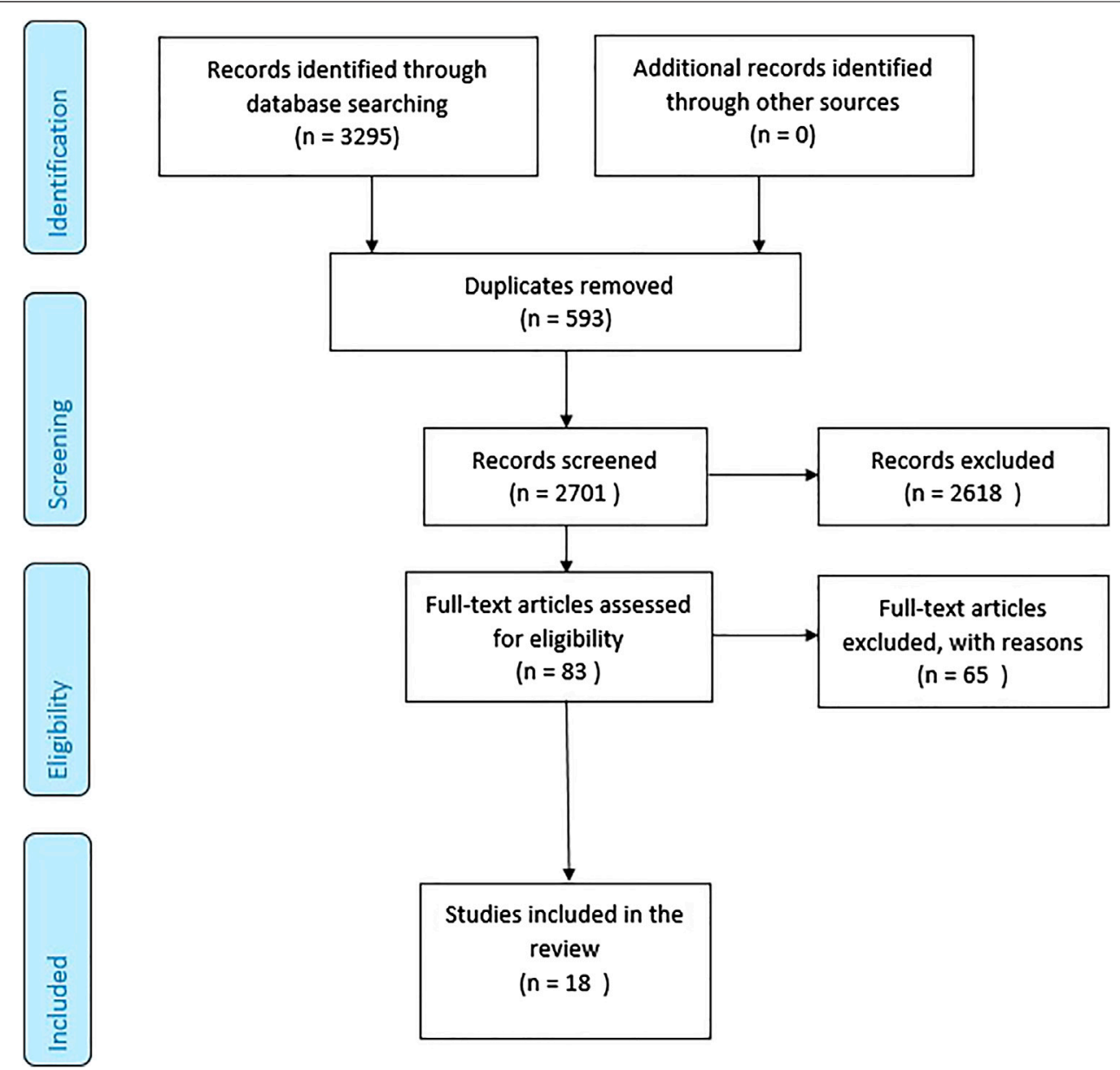

FIGURE 2 | PRISMA flow diagram.

\section{Charting the Data}

Data from the identified and included studies after the fulltext screening were independently extracted and entered in a data charting form by all three reviewers. The charting form was created beforehand in Microsoft Excel. Reviewers extracted the year of publication, study location, aim of the study, study population and size, study design, a detailed description of intervention used, outcome of the study, and key results.

\section{Collating, Summarizing, and Reporting the Results}

Data were analyzed quantitatively and descriptive statistics of basic characteristics of the studies were done; these statistics included distribution of studies by year or period of publication, countries of origin, type of intervention, study population, sample size, study aims, outcomes assessed, key findings, and study design; the summaries were presented in tables. The logical model was expanded and updated based on the results obtained.

\section{RESULTS}

The search yielded 3,295 records, and once the studies were uploaded in Covidence, 593 studies were automatically detected and removed as duplicates, and 83 were shortlisted for full-text screening. Eighteen studies were eligible for inclusion in the scoping review as shown in the prisma flow diagram (Figure 2). The studies included in the review were primary studies with 12 RCTs and two mixed-methods study designs, and other studies were cross sectional, random evaluation, nonrandomized study, and one study, however, did not state the study design used. The included studies covered one or more interventions' category (Table 1) provision of funding, school-based interventions for learners, community-based interventions, and education systems intervention. 10 studies implemented funding incentive intervention, 12 studies implemented school-based interventions for learners, six implemented community-based interventions, and three studies implemented education systems interventions. Table $\mathbf{1}$ shows the different types of intervention categories for each study. The included studies were published from 2007 to 2019. 
TABLE 1 | Overview of types of interventions covered by included studies.

\begin{tabular}{|c|c|c|c|c|c|c|c|}
\hline & Author & Year & Country & Funding incentive & $\begin{array}{c}\text { School-based } \\
\text { intervention learners }\end{array}$ & $\begin{array}{c}\text { Education } \\
\text { systems interventions }\end{array}$ & Community-based interventions \\
\hline 1 & Hyunsan Cho & 2017 & Kenya & Yes & & & \\
\hline 2 & Hyunsan Cho & 2018 & Kenya & Yes & Yes & & \\
\hline 3 & Deon Filmer & 2008 & Cambodia & Yes & & & Yes \\
\hline 4 & Denize Hallfors & 2011 & Zimbabwe & Yes & Yes & & \\
\hline 5 & Denize D. Hallfors & 2012 & Kenya & Yes & & & Yes \\
\hline 6 & Denize D. Hallfors & 2015 & Zimbabwe & Yes & Yes & & \\
\hline 7 & Bonita J. Iritani & 2015 & Zimbabwe & Yes & Yes & & \\
\hline 8 & Mutale Sampa & 2018 & Zambia & Yes & & & Yes \\
\hline 9 & Esther Duflo & 2007 & Kenya & Yes & & & \\
\hline 10 & Matthew C. Freeman & 2011 & Kenya & & Yes & Yes & \\
\hline 11 & Paul Montgomery & 2012 & Ghana & & Yes & & \\
\hline 12 & Winnie Mucherah & 2017 & Kenya & & Yes & & \\
\hline 13 & Emily Oster & 2011 & Nepal & & Yes & & \\
\hline 14 & Penelope A Phillips-Howard & 2016 & Kenya & & Yes & & \\
\hline 15 & Devika Mehra & 2018 & India & & & & Yes \\
\hline 16 & Garazi Zulaika & 2019 & Kenya & Yes & Yes & & \\
\hline 17 & Ravi Prakash & 2019 & India & & Yes & Yes & Yes \\
\hline 18 & Julie DeSoto & 2019 & Uganda & & Yes & Yes & Yes \\
\hline
\end{tabular}

Majority (14) of the studies were conducted in Africa; eight in Kenya, three in Zimbabwe, and one in Uganda, Ghana, and Zambia. However, four studies were conducted in South Asia; two in India, and one in Nepal and Cambodia. Characteristics of included studies are detailed in Table 2.

\section{Key Findings of the Studies}

Studies done by Cho in 2017 and 2018 found that payment of tuition fees, exam fees, and uniform costs to primary and secondary schools reduced the likelihood of dropping out of school, and increased the chances of transitioning from primary school to secondary school, and achieving higher grades (Cho et al., 2017; Cho et al., 2018). A study by Filmer found that the scholarship program increased enrollment and attendance (Filmer and Schady, 2008). Similarly, a study in Zimbabwe by Iritani found that a provision of school fees, uniform, school supplies, and a school-based "helper" reduced school dropout and absence, but the intervention did not improve test scores (Iritani et al., 2016).

The study by Freeman in Kenya found no significant impact on absenteeism after implementing a hygiene promotion and water treatment intervention (Freeman et al., 2012). A study in Ghana by Montgomery found that after 3 months of implementation of a program providing pads with education, there was improved attendance among participants (Montgomery et al., 2012). Similar to the finding of the study by Montgomery, Mucherah assessing the impact of the provision of sanitary and puberty education in Kenya found that girls who were provided with pads and puberty education reported less negative impact on their school attendance and grades (Mucherah and Thomas, 2017). Contrary to the finding by Montgomery and Mucherah, a study done by Oster in Nepal 2011 found that there was little or no evidence of the effect of menstrual cups on school attendance (Oster and Thornton, 2011). In an ongoing study in Kenya, researchers intend to assess the impact of menstrual cups or cash transfer alone, or a combination of menstrual cups and cash transfer on school dropout (Zulaika et al., 2019).

The study done in Zambia by Sampa in 2018 found that receiving cash transfer reduced the chances of dropping out of school, early marriages, and early pregnancies (Sampa et al., 2018). In Kenya, Duflo in 2006 found that reducing the cost of education by paying for school uniforms reduced dropout rates, teen marriage, and childbearing (Duflo et al., 2006). The role of information was explored in India where a study found that youth information centers and exposure to mass media showed an effect in reducing early marriage and early pregnancy, and improved school retention (Mehra et al., 2018). The studies done in Zimbabwe by Hallfors in 2011 and 2015 found that a daily feeding program, provision of school fees and uniforms, and having a school-based helper to monitor attendance and resolve problems reduced school dropouts and child marriage (Hallfors et al., 2011; Hallfors et al., 2015). Another study by Hallfors done in Kenya 2012 found that school provision of uniforms, school fees, sanitary pads and underpants for girls, monthly food supplements for the households, and community visitors reduced school dropouts and child marriage and pregnancies (Hallfors et al., 2012). All the funding incentive interventions in our scoping review focused on conditional cash transfers; we did not find any studies related to unconditional cash transfers in LMICs.

A study done in Uganda by DeSoto found that early warning system led to significant reduction in the number of girls who dropped out of school. The qualitative component of the study found that four out of five teachers who were interviewed said the reduction in school dropouts was due to increased sensitization of and awareness caused by the project on the value of girl child education among parents and community (Desoto et al., 2019). A study done by Prakash in India found that there was no difference in the proportion of girls completing secondary school education between the intervention group and the control group, $75.1 \%$ and 74.6\%, respectively (Prakash et al., 2019). 
TABLE 2 | Characteristics of included studies.

\begin{tabular}{|c|c|c|c|c|c|c|c|c|c|c|}
\hline & Author & Year & Country & Population & $\begin{array}{l}\text { Sample } \\
\text { size }\end{array}$ & $\begin{array}{l}\text { Study } \\
\text { design }\end{array}$ & Intervention & $\begin{array}{l}\text { Intervention } \\
\text { category }\end{array}$ & $\begin{array}{l}\text { Primary } \\
\text { outcome }\end{array}$ & $\begin{array}{l}\text { Secondary } \\
\text { outcome }\end{array}$ \\
\hline 1 & $\begin{array}{l}\text { Hyunsan } \\
\text { Cho }\end{array}$ & 2017 & Kenya & $\begin{array}{l}\text { Orphaned } \\
\text { boys and girls } \\
\text { in primary in } \\
\text { grade } 7 \text { and } 8\end{array}$ & 923 & $\begin{array}{l}\text { Cluster } \\
\text { randomized } \\
\text { control trial } \\
\text { Direct }\end{array}$ & $\begin{array}{l}\text { Payment of tuition, } \\
\text { exam fees, and } \\
\text { uniform costs to } \\
\text { primary and } \\
\text { secondary schools }\end{array}$ & Funding incentive & $\begin{array}{l}\text { Improving } \\
\text { educational } \\
\text { outcomes } \\
\text { (School } \\
\text { absence, } \\
\text { school } \\
\text { dropouts) }\end{array}$ & N/A \\
\hline 2 & $\begin{array}{l}\text { Hyunsan } \\
\text { Cho }\end{array}$ & 2018 & Kenya & $\begin{array}{l}\text { Orphaned } \\
\text { boys and girls } \\
\text { in primary in } \\
\text { grade } 7 \text { and } 8\end{array}$ & 835 & $\begin{array}{l}\text { Cluster } \\
\text { randomized } \\
\text { control trial }\end{array}$ & $\begin{array}{l}\text { Structural } \\
\text { intervention: } \\
\text { Provision of School } \\
\text { uniforms, payment } \\
\text { of tuition when } \\
\text { they transitioned } \\
\text { into high school, } \\
\text { and nurse visits to } \\
\text { monitor school } \\
\text { absenteeism }\end{array}$ & $\begin{array}{l}\text { Funding incentive } \\
\text { and School based } \\
\text { intervention for } \\
\text { learners }\end{array}$ & $\begin{array}{l}\text { Reducing the } \\
\text { risk of HIV } \\
\text { infection }\end{array}$ & $\begin{array}{l}\text { Education } \\
\text { outcomes } \\
\text { (School } \\
\text { dropout, } \\
\text { Highest grade } \\
\text { achieved) }\end{array}$ \\
\hline 3 & Deon Filmer & 2008 & Cambodia & $\begin{array}{l}\text { Girls beginning } \\
\text { 7th grade }\end{array}$ & 45 & $\begin{array}{l}\text { Cluster } \\
\text { randomized } \\
\text { control trial }\end{array}$ & $\begin{array}{l}\text { Japan fund for } \\
\text { poverty reduction } \\
\text { (JFPR) scholarship } \\
\text { program ( } \$ 45 \text { per } \\
\text { girl, conditional } \\
\text { cash transfers to } \\
\text { parents) }\end{array}$ & $\begin{array}{l}\text { Funding incentive } \\
\text { and community } \\
\text { based } \\
\text { intervention }\end{array}$ & $\begin{array}{l}\text { To increase the } \\
\text { enrollment of } \\
\text { girls in } \\
\text { secondary } \\
\text { school in } \\
\text { Cambodia }\end{array}$ & $\mathrm{N} / \mathrm{A}$ \\
\hline 4 & $\begin{array}{l}\text { Matthew C. } \\
\text { Freeman }\end{array}$ & 2011 & Kenya & $\begin{array}{l}\text { Primary School } \\
\text { boys and girls }\end{array}$ & 6,036 & $\begin{array}{l}\text { Cluster } \\
\text { randomized } \\
\text { control trial }\end{array}$ & $\begin{array}{l}\text { School-based } \\
\text { water treatment, } \\
\text { hygiene and } \\
\text { sanitation program }\end{array}$ & $\begin{array}{l}\text { School based } \\
\text { intervention and } \\
\text { education } \\
\text { systems } \\
\text { interventions }\end{array}$ & Pupil absence & N/A \\
\hline 5 & $\begin{array}{l}\text { Denize } \\
\text { Hallfors }\end{array}$ & 2011 & Zimbabwe & $\begin{array}{l}\text { Orphan girls in } \\
\text { grade } 6\end{array}$ & 329 & $\begin{array}{l}\text { Cluster } \\
\text { randomized } \\
\text { control trial }\end{array}$ & $\begin{array}{l}\text { Daily feeding } \\
\text { program, school } \\
\text { fees, uniforms, and } \\
\text { a school-based } \\
\text { helper to monitor } \\
\text { attendance and } \\
\text { resolve problems }\end{array}$ & $\begin{array}{l}\text { Funding } \\
\text { incentives, and } \\
\text { School based } \\
\text { interventions for } \\
\text { learners }\end{array}$ & $\begin{array}{l}\text { Risk of orphan } \\
\text { girls getting } \\
\text { infected } \\
\text { with HIV }\end{array}$ & $\begin{array}{l}\text { School dropout, } \\
\text { marriage, and } \\
\text { pregnancy rates }\end{array}$ \\
\hline 6 & $\begin{array}{l}\text { Denize D. } \\
\text { Hallfors }\end{array}$ & 2012 & Kenya & $\begin{array}{l}\text { Orphaned } \\
\text { children } \\
11-14 \text { years }\end{array}$ & 105 & $\begin{array}{l}\text { Cluster } \\
\text { randomized } \\
\text { control trial }\end{array}$ & $\begin{array}{l}\text { School uniforms, } \\
\text { school fees, } \\
\text { sanitary pads and } \\
\text { underpants for } \\
\text { girls, monthly food } \\
\text { supplements for } \\
\text { the households, } \\
\text { and community } \\
\text { visitors }\end{array}$ & $\begin{array}{l}\text { Funding } \\
\text { incentives and } \\
\text { community based } \\
\text { interventions }\end{array}$ & $\begin{array}{l}\text { School } \\
\text { retention }\end{array}$ & $\begin{array}{l}\text { Reducing HIV } \\
\text { risk factors }\end{array}$ \\
\hline 7 & $\begin{array}{l}\text { Denize D. } \\
\text { Hallfors }\end{array}$ & 2015 & Zimbabwe & $\begin{array}{l}\text { Adolescent } \\
\text { female } \\
\text { orphans }\end{array}$ & 328 & $\begin{array}{l}\text { Cluster } \\
\text { randomized } \\
\text { control trial }\end{array}$ & $\begin{array}{l}\text { School fees, } \\
\text { uniforms, supplies } \\
\text { and a school- } \\
\text { based female } \\
\text { "helper" } \\
\text { School fees for the } \\
\text { control in } 2011\end{array}$ & $\begin{array}{l}\text { Funding } \\
\text { incentives and } \\
\text { School based } \\
\text { interventions for } \\
\text { learners }\end{array}$ & $\begin{array}{l}\text { Sexual debut, } \\
\text { School dropout, } \\
\text { Ever married, } \\
\text { Ever Pregnant, } \\
\text { years of } \\
\text { schooling } \\
\text { (Continued or }\end{array}$ & following page) \\
\hline
\end{tabular}


TABLE 2 | (Continued) Characteristics of included studies.

\begin{tabular}{|c|c|c|c|c|c|c|c|c|c|c|}
\hline & Author & Year & Country & Population & $\begin{array}{l}\text { Sample } \\
\text { size }\end{array}$ & $\begin{array}{l}\text { Study } \\
\text { design }\end{array}$ & Intervention & $\begin{array}{l}\text { Intervention } \\
\text { category }\end{array}$ & $\begin{array}{l}\text { Primary } \\
\text { outcome }\end{array}$ & $\begin{array}{l}\text { Secondary } \\
\text { outcome }\end{array}$ \\
\hline 8 & $\begin{array}{l}\text { Bonita } \\
\text { J. Iritani }\end{array}$ & 2015 & Zimbabwe & $\begin{array}{l}\text { Orphan girls in } \\
\text { grade } 6\end{array}$ & 328 & $\begin{array}{l}\text { Cluster } \\
\text { randomized } \\
\text { control trial }\end{array}$ & $\begin{array}{l}\text { Fees, uniform, } \\
\text { school supplies, } \\
\text { and a school- } \\
\text { based "helper" } \\
\text { who monitored } \\
\text { and helped resolve } \\
\text { barriers to school } \\
\text { attendance } \\
\text { Delayed partial } \\
\text { school support to } \\
\text { the controls } \\
\text { (school fees only) }\end{array}$ & $\begin{array}{l}\text { Funding } \\
\text { incentives and } \\
\text { School based } \\
\text { interventions for } \\
\text { learners }\end{array}$ & $\begin{array}{l}\text { Academic } \\
\text { progression } \\
\text { (School } \\
\text { dropout, } \\
\text { academic } \\
\text { performance) }\end{array}$ & $\mathrm{N} / \mathrm{A}$ \\
\hline 9 & $\begin{array}{l}\text { Paul } \\
\text { Montgomery }\end{array}$ & 2012 & Ghana & $\begin{array}{l}\text { School girls } \\
\text { aged 12-18 }\end{array}$ & 120 & $\begin{array}{l}\text { Non } \\
\text { randomized } \\
\text { trial }\end{array}$ & $\begin{array}{l}\text { Provision of pads } \\
\text { with puberty } \\
\text { education; puberty } \\
\text { education alone }\end{array}$ & $\begin{array}{l}\text { School based } \\
\text { interventions for } \\
\text { learners }\end{array}$ & $\begin{array}{l}\text { School } \\
\text { attendance }\end{array}$ & N/A \\
\hline 10 & $\begin{array}{l}\text { Winnie } \\
\text { Mucherah }\end{array}$ & 2017 & Kenya & $\begin{array}{l}\text { Girls in grade } \\
6,7, \text { and } 8\end{array}$ & 150 & Not stated & $\begin{array}{l}\text { Provision reusable } \\
\text { cloth pads. } \\
\text { Education on how } \\
\text { to use the pads }\end{array}$ & $\begin{array}{l}\text { School based } \\
\text { interventions for } \\
\text { learners }\end{array}$ & $\begin{array}{l}\text { School } \\
\text { attendance and } \\
\text { performance }\end{array}$ & $\mathrm{N} / \mathrm{A}$ \\
\hline 11 & Emily Oster & 2011 & Nepal & $\begin{array}{l}\text { Girls in grade } 7 \text {, } \\
\text { and } 8\end{array}$ & 200 & $\begin{array}{l}\text { Random } \\
\text { evaluation }\end{array}$ & $\begin{array}{l}\text { Menstrual cup and } \\
\text { instructions } \\
\text { Booklets of time } \\
\text { diaries for each } \\
\text { month }\end{array}$ & $\begin{array}{l}\text { School based } \\
\text { interventions for } \\
\text { learners }\end{array}$ & $\begin{array}{l}\text { School } \\
\text { attendance }\end{array}$ & $\mathrm{N} / \mathrm{A}$ \\
\hline 12 & $\begin{array}{l}\text { Devika } \\
\text { Mehra }\end{array}$ & 2018 & India & $\begin{array}{l}\text { Young boys } \\
\text { and girls }\end{array}$ & 1,770 & $\begin{array}{l}\text { Cross-section } \\
\text { (post-test) }\end{array}$ & $\begin{array}{l}\text { Youth information } \\
\text { centers and } \\
\text { exposure to mass } \\
\text { media }\end{array}$ & $\begin{array}{l}\text { Community } \\
\text { based } \\
\text { interventions }\end{array}$ & $\begin{array}{l}\text { Early marriage, } \\
\text { early pregnancy } \\
\text { and school } \\
\text { retention }\end{array}$ & $\mathrm{N} / \mathrm{A}$ \\
\hline 13 & $\begin{array}{l}\text { Penelope A } \\
\text { Phillips- } \\
\text { Howard }\end{array}$ & 2016 & Kenya & $\begin{array}{l}\text { School girls } \\
14-16 \text { years } \\
\text { old }\end{array}$ & 555 & $\begin{array}{l}\text { Cluster } \\
\text { randomized } \\
\text { controlled } \\
\text { feasibility } \\
\text { study }\end{array}$ & $\begin{array}{l}\text { Insertable } \\
\text { menstrual cup, or } \\
\text { monthly sanitary } \\
\text { pads }\end{array}$ & $\begin{array}{l}\text { School based } \\
\text { interventions for } \\
\text { learners }\end{array}$ & $\begin{array}{l}\text { school attrition } \\
\text { (drop-out, } \\
\text { absence) }\end{array}$ & $\begin{array}{l}\text { Sexually } \\
\text { transmitted } \\
\text { infection }\end{array}$ \\
\hline 14 & $\begin{array}{l}\text { Mutale } \\
\text { Sampa }\end{array}$ & 2018 & Zambia & $\begin{array}{l}\text { Adolescent } \\
\text { girls in grade } 7\end{array}$ & 3,500 & $\begin{array}{l}\text { Cluster } \\
\text { randomized } \\
\text { controlled trial }\end{array}$ & $\begin{array}{l}\text { Monthly cash } \\
\text { transfer, payment } \\
\text { of school fees, } \\
\text { books, uniforms } \\
\text { and parents/ } \\
\text { guardians are } \\
\text { given money once } \\
\text { a year, and } \\
\text { community } \\
\text { dialogue }\end{array}$ & $\begin{array}{l}\text { Funding } \\
\text { incentives and } \\
\text { community based } \\
\text { intervention }\end{array}$ & School dropout & $\begin{array}{l}\text { Early marriages, } \\
\text { early } \\
\text { pregnancies }\end{array}$ \\
\hline 15 & Esther Duflo & 2007 & Kenya & $\begin{array}{l}\text { Students } \\
\text { enrolled in } \\
\text { grade } 5 \text { to } 8\end{array}$ & 74,000 & $\begin{array}{l}\text { Cluster } \\
\text { randomized } \\
\text { controlled trial }\end{array}$ & $\begin{array}{l}\text { Reducing the cost } \\
\text { of education by } \\
\text { providing free } \\
\text { uniforms }\end{array}$ & $\begin{array}{l}\text { Funding } \\
\text { incentives }\end{array}$ & $\begin{array}{l}\text { HIV/AIDS } \\
\text { prevention }\end{array}$ & $\begin{array}{l}\text { Reducing } \\
\text { school dropouts }\end{array}$ \\
\hline 16 & $\begin{array}{l}\text { Garazi } \\
\text { Zulaika }\end{array}$ & 2019 & Kenya & $\begin{array}{l}\text { Secondary } \\
\text { school } \\
\text { adolescent } \\
\text { girls }\end{array}$ & 3,960 & $\begin{array}{l}\text { Cluster } \\
\text { randomized } \\
\text { controlled trial }\end{array}$ & $\begin{array}{l}\text { To determine the } \\
\text { impact of } \\
\text { menstrual cups or } \\
\text { cash transfer } \\
\text { alone, or in } \\
\text { combination, on a } \\
\text { composite of } \\
\text { deleterious } \\
\text { outcomes (HIV, } \\
\text { HSV-2, and school } \\
\text { dropout) }\end{array}$ & $\begin{array}{l}\text { Funding incentive } \\
\text { and School based } \\
\text { interventions for } \\
\text { learners }\end{array}$ & $\begin{array}{l}\text { HIV, HSV-2, } \\
\text { and school } \\
\text { dropout) }\end{array}$ & $\begin{array}{l}\text { Safety of } \\
\text { menstrual cups }\end{array}$ \\
\hline
\end{tabular}


TABLE 2 | (Continued) Characteristics of included studies.

\begin{tabular}{|c|c|c|c|c|c|c|c|c|c|c|}
\hline & Author & Year & Country & Population & $\begin{array}{l}\text { Sample } \\
\text { size }\end{array}$ & $\begin{array}{l}\text { Study } \\
\text { design }\end{array}$ & Intervention & $\begin{array}{l}\text { Intervention } \\
\text { category }\end{array}$ & $\begin{array}{l}\text { Primary } \\
\text { outcome }\end{array}$ & $\begin{array}{l}\text { Secondary } \\
\text { outcome }\end{array}$ \\
\hline 17 & Ravi Prakash & 2019 & India & $\begin{array}{l}\text { Adolescent } \\
\text { girls aged } \\
\text { 12-13 years } \\
\text { enrolled in } \\
\text { standard } 7\end{array}$ & 2,457 & $\begin{array}{l}\text { Mixed method } \\
\text { approach/ } \\
\text { Cluster } \\
\text { randomized } \\
\text { controlled trial }\end{array}$ & $\begin{array}{l}\text { i) Establishing safe } \\
\text { spaces for girls to } \\
\text { meet and develop } \\
\text { life skills, ii) } \\
\text { providing } \\
\text { academic tutoring } \\
\text { for girls, iii) forming } \\
\text { boys' sports } \\
\text { groups to sensitize } \\
\text { boys to appreciate } \\
\text { girls' rights and } \\
\text { treat girls } \\
\text { respectively, iv) } \\
\text { sensitizing parents } \\
\text { to value girls' } \\
\text { education and } \\
\text { challenging norms } \\
\text { around age of girl } \\
\text { child marriage, and } \\
\text { v) linking families to } \\
\text { government } \\
\text { financial incentives } \\
\text { for girls in school. } \\
\text { Introducing girls } \\
\text { tracking systems, } \\
\text { introduce school } \\
\text { safety policies, } \\
\text { train school staff } \\
\text { on issues around } \\
\text { gender and girl } \\
\text { school drop-out, } \\
\text { and strengthening } \\
\text { the school } \\
\text { governing } \\
\text { committees }\end{array}$ & $\begin{array}{l}\text { School based } \\
\text { interventions for } \\
\text { learners, } \\
\text { community based } \\
\text { intervention and } \\
\text { education } \\
\text { systems } \\
\text { interventions }\end{array}$ & $\begin{array}{l}\text { Completion of } \\
\text { secondary } \\
\text { school and } \\
\text { marriage at the } \\
\text { end of the trial }\end{array}$ & $\begin{array}{l}\text { Transitioning to } \\
\text { secondary } \\
\text { school, passing } \\
\text { secondary } \\
\text { school exams, } \\
\text { and sexual } \\
\text { debut }\end{array}$ \\
\hline 18 & Julie DeSoto & 2019 & Uganda & $\begin{array}{l}\text { Secondary } \\
\text { school } \\
\text { adolescent } \\
\text { girls }\end{array}$ & $\begin{array}{c}5 \\
\text { schools }\end{array}$ & $\begin{array}{l}\text { Mixed } \\
\text { methods } \\
\text { longitudinal } \\
\text { design }\end{array}$ & $\begin{array}{l}\text { Early warning } \\
\text { system }\end{array}$ & $\begin{array}{l}\text { School based } \\
\text { interventions for } \\
\text { learners, } \\
\text { community based } \\
\text { intervention } \\
\text { education } \\
\text { systems } \\
\text { interventions }\end{array}$ & $\begin{array}{l}\text { Retention in } \\
\text { secondary } \\
\text { schools }\end{array}$ & \\
\hline
\end{tabular}

Based on these findings, we update the logic model as shown in Figure 3. The updated logic model was updated by adding interventions and outcomes as a result of the implemented interventions from the 18 included studies. The updated logic model shows the interventions to keep adolescent girls in school and how the intervention may influence the adolescent girls' lives. In the updated logic model, it is shown that interventions can lead to increased chances of girls staying in school, increased enrolments, reduced school absence, reduced early pregnancies, and early marriages. In the long run, the interventions can lead to high employment opportunities, reduced child and maternal mortality, increased access to quality medical services, high literacy levels, and more.

\section{DISCUSSION}

Sustainable Development Goal number 4.1, whose target is to "ensure that all girls and boys complete free, equitable, and quality primary and secondary education, leading to relevant and effective learning outcomes by 2030," poses a critical need for governments and all stakeholders to structure interventions that minimize the disparities in education attainment between boys and girls. We conducted a comprehensive scoping review of studies that looked at interventions to keep adolescent girls in school in LMICs. Our review included 18 studies conducted in Cambodia, Ghana, India, Kenya, Nepal, and Zimbabwe. Of these, 12 studies were randomized controlled trials (RCTs). The interventions evaluated were mainly funding incentives and 


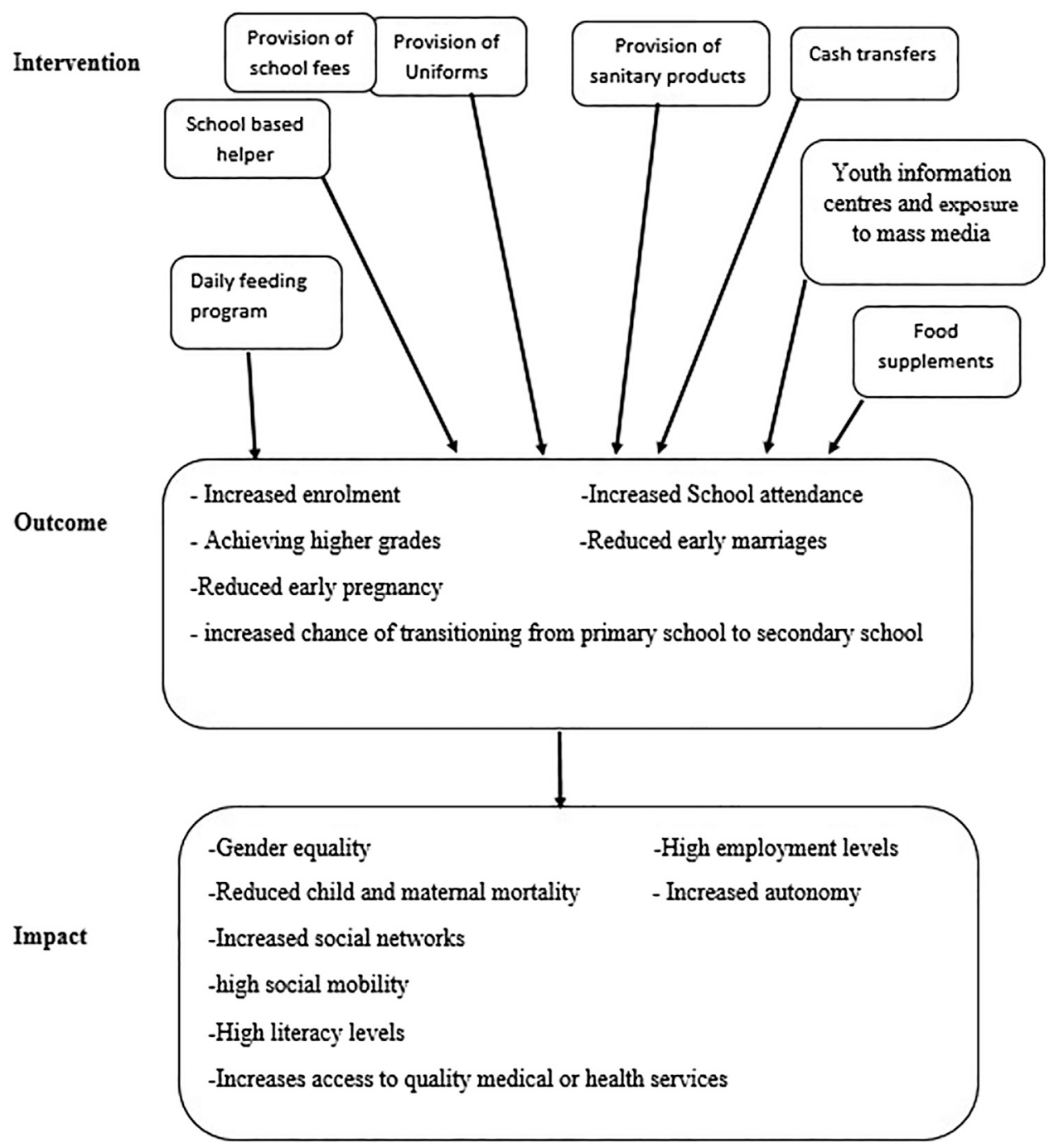

FIGURE 3 | Updated iterative logic model.

school-based interventions for learners, with a few on community-based and education systems.

School dropout is often linked with poverty; poverty affects the ability of households to pay school fees and other costs associated with education. In our scoping review (Duflo et al., 2006; Hallfors et al., 2011; Hallfors et al., 2012; Hallfors et al., 2015; Iritani et al., 2016; Cho et al., 2017; Cho et al., 2018), the studies show that supporting household with costs associated with schooling such as payment of school fees, provision of uniforms, and other materials reduces dropouts. These cash transfers were all conditioned upon the girls attending school, an approach that implies a top-down approach in decision-making. In such interventions, the parents are the recipients of the decision by stakeholders and various organizations to send girls to school (Bundy et al., 2017). Several studies have suggested that interventions conditional upon school attendance have a pronounced impact of about $60 \%$ improvement in enrollment compared to interventions with no conditions (Baird et al., 2011; Baird et al., 2014; Benhassine et al., 2015; Akresh et al., 2016).

The funding incentive intervention category was the second most common intervention, and it included the provision of school fees, school uniforms, stipends, and provision of sanitary towels. However, the most prominent type of intervention in the scoping review was the provision of school fees and school uniforms. However, the associated limitation with interventions that provide monetary support is sustainability when the program comes to an end (Cross et al., 2018). These interventions are seen to yield favorable results in relation to keeping adolescent girls as well as adolescent boys in school. Therefore, researcher can still implement more funding intervention in order to continue keeping adolescent girls in school; however, these interventions should be implemented with proper sustainability plan for when the program comes to an end. The other type of intervention under the funding incentive 
category was the provision of sanitary towels to adolescent girls, studies by (Montgomery et al., 2012; Mucherah and Thomas, 2017) have shown that there is a positive relationship between providing adolescent girls with sanitary towels and improving their education outcome such as school attendance and improved grades. There is need for researchers to continue fighting adolescent girls' school dropouts through the provision of sanitary towels and more.

The scoping review has identified that a number of different interventions have been conducted in an effort to keep adolescent girls in school, and in this scoping review, the search for studies only picked primary studies. However, in order to explicitly indicate and recommend which interventions work best to keep adolescent girls in school, we recommend that systematic reviews be done on individual interventions, and then an overview of reviews could be done afterward.

The possible limitations in this scoping review were that the review may have missed some relevant studies, and this limitation may be attributed to database selection (i.e., searching other databases may have identified additional relevant studies); therefore, relevant sources of information may be omitted, and the review is dependent on information on the review question being available. The other limitation was that grey literature was excluded from the search. In a scoping review, no rating of the quality of evidence is provided; therefore, implications for practice or policy cannot be graded.

\section{CONCLUSION}

The scoping review included studies with interventions categorized as funding incentives, school-based interventions for learners, community-based interventions, and education systems. These interventions were generally found to reduce school dropouts, and increase enrollment and school attendance. Majority of the intervention category in the 18 included studies was the school-based interventions for learners. However, the most prominent intervention was the provision of school fees and school uniforms; this intervention was part of the funding intervention category. Although most studies included in the scoping review were seen to have a positive effect on the education outcome of adolescent girls,

\section{REFERENCES}

Adato, M., and Bassett, L. (2009). Social protection to support vulnerable children and families: the potential of cash transfers to protect education, health and nutrition. AIDS care. 21 (sup1), 60-75.

Akresh, R., De Walque, D., and Kazianga, H. (2016). Evidence from a randomized evaluation of the household welfare impacts of conditional and unconditional cash transfers given to mothers or fathers. Washington, DC, USA: The World Bank.

Arksey, H., and O'malley, L. (2005). Scoping studies: towards a methodological framework. Int. J. Soc. Res. Methodol. 8 (1), 19-32. doi:10.1080/1364557032000119616

Baird, S., Mcintosh, C., and Özler, B. (2011). Cash or condition? Evidence from a cash transfer experiment. Q. J. Econ. 126 (4), 1709-1753. doi:10.1093/qje/qjr032 some studies had no evidence to support the effects observed. To the best of our knowledge, in our searches, we did not yield any systematic reviews on intervention to keep adolescent girls in school. The authors, therefore, propose to conduct a systematic review on the provision of sanitary towels to adolescent girls and its effect on retention in school in low- and middle-income countries.

\section{AUTHOR CONTRIBUTIONS}

All authors contributed to the scoping review. Screening of articles and extraction of data were done by MS, MM, and RF. The manuscript was drafted by MS with input from all authors. TY and PM reviewed the work throughout the scoping review process. TY critically revised the work. All authors read and approved the final manuscript.

\section{FUNDING}

The scoping review is supported by the Research, Evidence, and Development Initiative (READ-It) project. READ-It (project number 300342-104) is funded by United Kingdom aid from the United Kingdom government; however, the views expressed do not necessarily reflect the United Kingdom government's official policies.

\section{ACKNOWLEDGMENTS}

Paul Garner for providing guidance through the scoping review process, Vittoria Lutge for conducting the search for potential studies, and Herryman Moono for reviewing and proofreading the manuscript before submission to the journal.

\section{SUPPLEMENTARY MATERIAL}

The Supplementary Material for this article can be found online at: https://www.frontiersin.org/articles/10.3389/feduc.2020.614297/ full\#supplementary-material.

Baird, S., Ferreira, F. H., Özler, B., and Woolcock, M. (2014). Conditional, unconditional and everything in between: a systematic review of the effects of cash transfer programmes on schooling outcomes. J. Dev. Effect. 6 (1), 1-43. doi:10.1080/19439342.2014.890362

Beattie, T. S., Bhattacharjee, P., Isac, S., Davey, C., Javalkar, P., Nair, S., et al. (2015). Supporting adolescent girls to stay in school, reduce child marriage and reduce entry into sex work as HIV risk prevention in north Karnataka, India: protocol for a cluster randomised controlled trial. BMC Publ. Health 15 (1), 292. doi:10. 1186/s12889-015-1623-7

Benhassine, N., Devoto, F., Duflo, E., Dupas, P., and Pouliquen, V. (2015). Turning a shove into a nudge? A "labeled cash transfer" for education. Am. Econ. J. Econ. Pol. 7, 86-125. doi:10.3386/w19227

Bundy, D. A., Silva, N., Horton, S., Jamison, D. T., and Patton, G. C. (2017). Cash transfers and child and adolescent development-child and adolescent health and 
development. Washington, DC, USA: The International Bank for Reconstruction and Development/The World Bank.

Cho, H., Catherine Ryberg, R., Hwang, K., Pearce, L. D., and Iritani, B. J. (2017). A school support intervention and educational outcomes among orphaned adolescents: results of a cluster randomized controlled trial in Kenya. Prev. Sci. 18 (8), 943-954. doi:10.1007/s11121-017-0817-x

Cho, H., Mbai, I., Luseno, W. K., Hobbs, M., Halpern, C., and Hallfors, D. D. (2018). School support as structural HIV prevention for adolescent orphans in Western Kenya. J. Adolesc. Health 62 (1), 44-51. doi:10.1016/j.jadohealth.2017. 07.015

Covidence systematic review software (2019). Veritas health innovation, melbourne, Australia. Available at: http://www.covidence.org (Accessed December 3, 2020).

Cross, A., Manell, T., and Megevand, M. (2018). "Humanitarian cash transfer programming and gender-based violence outcomes: evidence and future research Priorities," in Collected papers on gender and cash transfer programmes in humanitarian contexts, Geneva: WRC and IRC, 97-122.

Desoto, J., Laura, R., and Belsan, A. (2019). 170. Keeping Ugandan girls in school and safe from HIV: results from an integrated adolescent-led early warning system. J. Adolesc. Health 64 (2), S87. doi:10.1016/j.jadohealth.2018.10.186

Duflo, E., Dupas, P., Kremer, M., and Sinei, S. (2006). Education and HIV/AIDS prevention: evidence from a randomized evaluation in Western Kenya. Washington, DC, USA: The World Bank.

Filmer, D., and Schady, N. (2008). Getting girls into school: evidence from a scholarship program in Cambodia. Econ. Dev. Cult. Change 56 (3), 581-617. doi:10.1086/533548

Freeman, M. C., Greene, L. E., Dreibelbis, R., Saboori, S., Muga, R., Brumback, B., et al. (2012). Assessing the impact of a school-based water treatment, hygiene and sanitation programme on pupil absence in Nyanza Province, Kenya: a cluster-randomized trial. Trop. Med. Int. Health 17 (3), 380-391. doi:10.1111/j. 1365-3156.2011.02927.x

Hallfors, D., Cho, H., Rusakaniko, S., Iritani, B., Mapfumo, J., and Halpern, C. (2011). Supporting adolescent orphan girls to stay in school as HIV risk prevention: evidence from a randomized controlled trial in Zimbabwe. Am. J. Publ. Health 101, 1082-1088. doi:10.2105/AJPH.2010.300042

Hallfors, D. D., Cho, H., Mbai, I., Milimo, B., and Itindi, J. (2012). Process and outcome evaluation of a community intervention for orphan adolescents in Western Kenya. J. Community Health 37, 1101-1109. doi:10.1007/s10900-0129548-x

Hallfors, D. D., Cho, H., Rusakaniko, S., Mapfumo, J., Iritani, B., Zhang, L., et al. (2015). The impact of school subsidies on HIV-related outcomes among adolescent female orphans. J. Adolesc. Health, 56, 79-84. doi:10.1016/j.jadohealth.2014.09.004

Iritani, B. J., Cho, H., Rusakaniko, S., Mapfumo, J., Hartman, S., and Hallfors, D. D. (2016). Educational outcomes for orphan girls in rural Zimbabwe: effects of a school support intervention. Health Care Women Int. 37, 301-322. doi:10.1080/ 07399332.2015.1017641

Kharisma, B., Satriawan, E., and Arsyad, L. (2017). The impact of social safety net scholarships program to school dropout rates in Indonesia: the intention-totreat analysis. J. Develop. Area. 51 (4), 303-316. doi:10.1353/jda.2017.0103

Mcintyre, P.World Health Organization, 2019 (2006). Pregnant adolescents: delivering on global promises of hope. Oxford, UK, Geneva, Switzerland: WHO Document Production Services

Mehra, D., Sarkar, A., Sreenath, P., Behera, J., and Mehra, S. (2018). Effectiveness of a community based intervention to delay early marriage, early pregnancy and improve school retention among adolescents in India. BMC Public Health 18 (1), 732. doi:10.1186/s12889-018-5586-3

Mnguni, I. B. (2014). Investigating the causes of learner dropout at secondary schools in Johannesburg South, Gauteng. PhD Dissertation. University of South Africa.

Montgomery, P., Ryus, C. R., Dolan, C. S., Dopson, S., and Scott, L. M. (2012). Sanitary pad interventions for girls' education in Ghana: a pilot study. PLoS One 7 (10), e48274. doi:10.1371/journal.pone.0048274

Mucherah, W., and Thomas, K. (2017). Reducing barriers to primary school education for girls in rural Kenya: reusable pads' intervention. Int. J. Adolesc. Med. Health 31 (3). doi:10.1515/ijamh-2017-0005
Murphy, E., and Carr, D. (2007). Powerful partners: adolescent girls education and delayed childbearing. Washington, DC: Population Reference Bureau.

Nagar, S. E., Bamkar, S., and Tønnessen, L. (2017). Report No.: SR 2017:3. Girls, child marriage, and education in red sea state, sudan: perspectives on girls' freedom to choose.

Neal, S., Matthews, Z., Frost, M., Fogstad, H., Camacho, A. V., and Laski, L. (2012). Childbearing in adolescents aged 12-15 years in low resource countries: a neglected issue. New estimates from demographic and household surveys in 42 countries. Acta Obstet. Gynecol. Scand. 91, 1114-1118. doi:10.1111/j.1600-0412. 2012.01467.x

Oster, E., and Thornton, R. (2011). Menstruation, sanitary products, and school attendance: evidence from a randomized evaluation. Am. Econ. J. Appl. Econ. 31 (3), 91-100. doi:10.1257/app.3.1.91

Peters, M., Godfrey, C., McInerney, P., Soares, C., Khalil, H., and Parker, D. (2015). The Joanna Briggs Institute reviewers' manual 2015: methodology for JBI scoping reviews.

Prakash, R., Beattie, T. S., Javalkar, P., Bhattacharjee, P., Ramanaik, S., Thalinja, R. et al. (2019). The Samata intervention to increase secondary school completion and reduce child marriage among adolescent girls: results from a clusterrandomised control trial in India. J. Glob. Health 9, 010430. doi:10.7189/jogh. 09.010430

Sampa, M., Jacobs, C., and Musonda, P. (2018). Effect of cash transfer on school dropout rates using longitudinal data modelling: a randomized trial of research initiative to support the empowerment of girls (rise) in Zambia. Open Publ. Health J, 11 (1), 507-515. doi:10.2174/1874944501811010507

Sandøy, I. F., Mudenda, M., Zulu, J., Munsaka, E., Blystad, A., Makasa, M. C., et al. (2016). Effectiveness of a girls' empowerment programme on early childbearing, marriage and school dropout among adolescent girls in rural Zambia: study protocol for a cluster randomized trial. Trials 17 (1), 588. doi:10. 1186/s13063-016-1682-9

Tricco, A. C., Lillie, E., Zarin, W., O'Brien, K., Colquhoun, H., Kastner, M., et al. (2016). A scoping review on the conduct and reporting of scoping reviews. $B M C$ Med. Res. Methodol. 16 (1), 1-10.

Tricco, A. C., Lillie, E., Zarin, W., O’Brien, K. K., Colquhoun, H., Levac, D., et al. (2018). PRISMA extension for scoping reviews (PRISMA-ScR): checklist and explanation. Ann. Internal Med. 169 (7), 467-473.

UNESCO (2016). 263 Million Children and Youth Are Out of School. [Online] Available at: http://uis.unesco.org/en/news/263-million-children-and-youthare-out-school [Accessed January 26, 2021]

World Bank (2019). World Bank country and lending Groups. Available at: https://datahelpdesk.worldbank.org/knowledgebase/articles/906519-worldbank-country-and-lending-groups (Accessed December 6, 2020).

World Health Organization (2019). Handbook for conducting an adolescent health services barriers assessment (AHSBA) with a focus on disadvantaged adolescents: knowing which adolescents are being left behind on the path to universal health coverage, and why. Geneva, Switzerland: World Health Organization.

Zulaika, G., Kwaro, D., Nyothach, E., Wang, D., Zielinski-Gutierrez, E., Mason, L., et al. (2019). Menstrual cups and cash transfer to reduce sexual and reproductive harm and school dropout in adolescent schoolgirls: study protocol of a cluster-randomised controlled trial in western Kenya. BMC Public Health 19 (1), 1317. doi:10.1186/s12889-019-7594-3

Conflict of Interest: The authors declare that the research was conducted in the absence of any commercial or financial relationships that could be construed as a potential conflict of interest.

Copyright $\odot 2021$ Sampa, Musukuma, Fisa, Musonda and Young. This is an openaccess article distributed under the terms of the Creative Commons Attribution License (CC BY). The use, distribution or reproduction in other forums is permitted, provided the original author(s) and the copyright owner(s) are credited and that the original publication in this journal is cited, in accordance with accepted academic practice. No use, distribution or reproduction is permitted which does not comply with these terms. 